\title{
Anticancer and Apoptosis Induction Properties of Apium Graveolens Seeds
}

\author{
Article by Karthikeyan K, Ajikumaran Nair S and Subramoniam \\ A. Tropical Botanic Garden and Research Institute, Pacha-Palode \\ Email:- kkumar.karthi@gmail.com
}

\begin{abstract}
Based on traditional medicinal use Apium graveolens seed was selected to evaluate its anti-cancer property with special reference to apoptosis induction, if any. When the water, alcohol and hexane extracts of the dried powder of the plant seeds were tested for cytotoxicity to Dalton's Lymphoma Acitic (DLA) cells in vitro using Tryphan blue method, only the n-hexane extract showed significant activity at 500 $\mu \mathrm{g} / \mathrm{ml}$ level. The extract induced apoptosis as evidenced by morphological changes. The cytotoxicity of this extract was found to be more to cancer cells (DLA) compared to normal cells (thymocytes and macrophages). An active chloroform fraction was separated from this extract. The active fraction at a dose of $200 \mathrm{mg} / \mathrm{kg}$ protected $75 \%$ of the mice challenged with $1 \times 10^{6}$ DLA cells whereas all untreated control mice died of cancer. Thin Layer Chromatography (TLC) on silica gel further separated this anticancer fraction into 2 cytotoxic components. One of them was identified as a steroid positive component whereas the other was an alkaloid positive component. The steroid component induced apoptotic cell death while the other component induced necrotic cell death. These components are attractive materials for further studies leading to possible anti-cancer drug development.
\end{abstract}

Keywords: Apoptosis, Apium graveolens, Anticancer, Dalton's lymphoma ascetic

\section{Introduction}

Traditional medicinal plants are a rich source of pharmacologically active compounds. These plants are used by various cultural groups from ancient times onwards to treat various diseases including the dreaded disease cancer. These plants were identified for medicinal uses through human experiences, empirical knowledge and beliefs that existed in various periods of human evolution. Many of the herbal drugs are used improperly. Scientific evaluation of these medicinal plants in light of recent advances in medical sciences and therapy as well as modern methods of drug development is sure to revolutionize our health care and socio-economic conditions (1).

Cancer even today escaped the ingenuity of human, to a large extent, and poses a serious threat to modern civilization. Although there are many drugs in use to treat cancer patients, none of them is satisfactory to cure full grown cancers (2). Many plant based drugs discovered and developed through ethno-medical leads such as taxol, vincristine, vinblastine and camptothesin are currently used as chemotherapeutic agents and many more drugs are in various stages of studies $(3,4,5,6,7,8,9,10,11,12,13,14)$. There are many traditional anti-cancer plants, which remain to be studied in light of modern sciences $(1,15)$.

In this context, the discovery of apoptosis, one of the body's own mechanisms to remove unwanted cells including cancer cells, gives hope to use as a tool to screen medicinal plants for their possible anti-cancer activity $(16,17,18,19)$. If induction of apoptosis by phyto-chemicals turns out to be specific to cancer cells or specific type of cancer cells such compounds could likely to be invaluable anti-cancer agents (19).

There are many plant extracts and phytochemicals known to induce apoptosis (19). Search for cancer cell specific apoptosis inducing compounds, among anti-cancer 
South American Journal of Medicine

Special Edition 2016

plants is an interesting area to pursue. Based on compelling ethnomedical leads (20), Apium graveolens Linn. Apiaceae [Tamil: Oman; Malayalam: Ayamodakam; Sanskrit: Ajmoda; Hindi: Ajmud; English: Celery] was selected for screening for possible apoptosis inducing properties vis-à-vis developing better chemotherapy for cancer.

This plant is used in different parts of the world in traditional medicine to treat as well as prevent diverse types of cancer (20). Generally all parts of the plant, especially seed, leaves and flowers, are in use. The juice of the plant in the form of liquid or syrup or pills is given to treat/control various types of tumors (20). Crude seed extract of this plant was shown to be active against mosquitoes (21). It is currently used in traditional medicine, culinary, drugs, flavouring, food and perfumery (22).

\section{Material and methods}

\section{Plant materials}

Apium graveolens seeds were purchased from herbal drug market at Nanniyode, Thiruvananthapuram District. These materials were checked for authenticity by taxonomists at TBGRI.

\section{Chemicals and reagents}

Tryphan blue and Dimethyl sulfoxide (DMSO) were from Sigma Chemicals Co. St. Louis MO. All other chemicals and reagents used were analytical grade and purchased from E.Merk India Ltd. Mumbai and SRL, India

\section{Preparation of water extract}

The dried seeds were powdered and extracted with distilled water $(5 \mathrm{~g} / 100 \mathrm{ml})$ with constant stirring for $4 \mathrm{hrs}$ and then filtered through a filter paper. Residue was again extracted as above with water. The combined filtrate was freeze dried in a lyophiliser. The yield of the water extract was determined (10). (Since the heat sensitivity of the extract with reference to bio-activity is not known, the extraction was carried out at low temperature without using rigorous extraction procedures).

\section{Alcohol extract}

The alcohol extract of the plant powder was prepared similarly using ethyl alcohol instead of distilled water. However, in this case the combined extract was evaporated to dryness in a rotary evaporator under reduced pressure at $40{ }^{0} \mathrm{C}$ as described elsewhere (10). The yield of the alcohol extract was determined.

\section{Hexane extract}

The hexane extracts of the powder was prepared as above using n-hexane instead of alcohol. However, to ensure complete extraction $2 \mathrm{~g}$ powder was extracted with 100 $\mathrm{ml}$ hexane and the process was repeated 3 times. The filtrates from the extractions were combined and dried in a rotary evaporator under reduced pressure at $40{ }^{\circ} \mathrm{C}$. The yield of the hexane extract was determined.

\section{Animals}

Inbred Swiss albino mice (6-7 week old), reared in Tropical Botanic garden and Research Institute (TBGRI) animal house, were used. Animals were caged in uniform hygienic conditions and fed with standard pellet diet (Lipton, India Laboratories, Bangalore) and water ad libitum as per the guide lines of Institute Animal Ethics Committee.

\section{Cell Lines}

Dalton's Lymphoma Ascitic (DLA) cells, originally obtained from Amala Cancer 
Research Centre, Thrissur, India, were propagated as transplantable tumors in the peritoneal cavity of mice.

\section{Thymocyte preparation}

Thymus glands were removed from the mice carefully and trimmed off from the adjoining lymph nodes. Single cell suspensions were prepared in cold RPMI -1640 medium and viability assessed by Tryphan Blue exclusion method (23).

\section{Collection of macrophages}

Peritoneal exudates cells (PEC) were collected by injecting $5 \mathrm{ml}$ chilled RPMI1640 medium in peritoneal cavity of mice. The glass adherent cell population (macrophages) was separated by adhering PEC over glass petri-dishes at $37{ }^{\circ} \mathrm{C}$ for 2 hrs in a $\mathrm{CO} 2$ incubator having $5 \% \mathrm{CO} 2$ in air. The viable cell count was taken using Tryphan Blue in a Neubauer counting chamber.

\section{In vitro cytotoxicity assay}

Short-term cytotoxicity of extracts was assessed by incubating $1 \times 10^{6}$ DLA cells, thymocytes or macrophages in $1 \mathrm{ml}$ PBS containing different concentrations of extract. The cell viability was assessed by Trypan Blue exclusion method (23).

\section{Isolation of an active fraction from Apium graveolens}

The hexane extract from the plant seeds was suspended in water and extracted with chloroform and the chloroform fraction was tested for cytotoxicity. The active chloroform fraction was subjected to chemical analysis to determine the classes of compounds present in it (24). This active fraction was subjected to silica gel Thin Layer Chromatography (TLC) using hexane: chloroform: methanol (5:4:1) as a solvent system. The chromatograms were sprayed with different reagents to determine the quality of different components separated (24). Each spot in preparative TLC was identified (with the help of a reagent sprayed plate run simultaneously) based on relative mobility, scrapped off and eluted with chloroform; and tested for cytotoxicity and apoptotic cell death induction in DLA cells.

\section{In vivo anti-cancer assay}

In vivo anti-cancer activity was evaluated as described elsewhere (14) using DLA growth in the peritoneal cavity of mice as a model. Briefly, mice were divided into 6 groups with 8 animals in each group and were challenged with intraperitonial injection of $1 \times 10^{6}$ DLA cells. One group was kept as control without drug treatment. Group 2, 3 and 4 were administered the chloroform fraction of hexane extract of the seeds at 50,100 and $200 \mathrm{mg} / \mathrm{kg}$ respectively, daily, orally, starting from the day of tumour challenge. Group 5 and 6 received the standard drug vincristine at 0.5 and 1.0 $\mathrm{mg} / \mathrm{kg}$ respectively. The drugs were suspended in 5\% Tween 80 and administered. Control mice received the vehicle ( $0.5 \mathrm{ml} \mathrm{5 \%}$ Tween 80/mouse).

\section{Results}

The yields of water, alcohol and hexane extracts of A. graveolens (seed) were 20.7, 17.5 and $15 \%$ of the dry powder respectively.

The cytotoxicity data of the extracts to DLA cells are given in Table 1 and 2. The water extract did not show any toxicity to these cells up to $500 \mu \mathrm{g} / \mathrm{ml}$ studied. In contrast, the hexane extract showed $48 \%$ cell death at $50 \mu \mathrm{g} / \mathrm{ml}$ whereas alcohol extract showed almost the same level of toxicity at $500 \mu \mathrm{g} / \mathrm{ml}$. The cell death was associated with nuclear condensation, membrane blebbing (Fig.1) and formation of apoptotic bodies---characteristics of apoptotic cell death. The cyto-toxicity of the hexane extract to different cell types is shown in Table 2. The DLA cells (tumor cells) 
South American Journal of Medicine

Special Edition 2016

were more sensitive to this extract compared to macrophages (normal cells). Normal thymocytes were resistant to this extract up to $500 \mu \mathrm{g} / \mathrm{ml}$ studied.

An active chloroform fraction was separated from the hexane extract of $A$. graveolens. This fraction showed in vivo anti-cancer activity. At a dose of $200 \mathrm{mg} / \mathrm{kg}$, it protected $75 \%$ of the mice challenged with 1 X $10^{6}$ DLA cells whereas all untreated control mice died of cancer.

The chloroform fraction was separated on TLC into 3 components Out of the 3 components, 2 of them were found to have cytotoxicity (Table 3 ). One of the active spots, (Rf 0.60) showed positive to steroid (Liebermann Buchard spray). This spot showed fluorescence under UV light. Interestingly, this steroid positive component showed apoptosis-inducing property, while the other active spot (Rf 0.47) induced necrotic type of cell death. This showed positive to Dragendorff test for alkaloids (24).

Table 1. Cytotoxicity of different extracts of Apium graveolens on DLA cells incubated at $37{ }^{\circ} \mathrm{C}$ in PBS.

\begin{tabular}{|l|c|c|}
\hline Test material & Quantity of extract $(\mu \mathrm{g} / \mathrm{ml})$ & $\%$ cell death \\
\hline $0.1 \%$ DMSO (Control) & 0 & 0 \\
\hline \multirow{3}{*}{ Water extract } & 50 & 0 \\
& 125 & 0 \\
& 250 & 0 \\
Alcohol extract & 500 & 0 \\
& 50 & 0 \\
& 125 & $11 \pm 1$ \\
& 250 & $51 \pm 3$ \\
\hline Hexane extract & 500 & $78 \pm 3$ \\
& 50 & $100 \pm 0$ \\
& 125 & $100 \pm 0$ \\
\hline
\end{tabular}

Values are mean \pm S.D of 3 separate determinations

(Values are corrected to whole number). Cytotoxicity was determined by Trypan Blue exclusion method.

Table 2. In vitro cytotoxicity of n-hexane extract of apium graveolens to different cells incubated for 3 hours in PBS.

\begin{tabular}{|l|c|c|c|}
\hline \multirow{2}{*}{$\begin{array}{l}\text { Apium graveolens Hexane } \\
\text { extract }(\mu \mathrm{g} / \mathrm{ml})\end{array}$} & \multicolumn{3}{|c|}{ \% cell death } \\
\cline { 2 - 4 } & DLA & Macrophages & Thymocytes \\
\hline $0.1 \%$ DMSO $($ Control $)$ & 0 & 0 & 0 \\
\hline 250 & 100 & $61 \pm 2$ & 0 \\
\hline 500 & 100 & $82 \pm 4$ & 0 \\
\hline
\end{tabular}

Values are mean \pm S.D of 3 separate determinations Cytotoxicity was determined by Trypan Blue exclusion method.

Table 3. In vitro cytotoxicity to DLA cells of the chemical isolates from the active chloroform fraction from apium graveolens

\begin{tabular}{|c|c|c|}
\hline \multirow[b]{2}{*}{ Concentration $(\mu \mathrm{g} / \mathrm{ml})$} & \multicolumn{2}{|c|}{$\%$ cell death } \\
\hline & $\begin{array}{lll}\begin{array}{l}\text { Chemical Isolate } \\
0.60)\end{array} & & (\mathrm{Rf} \\
\end{array}$ & $\begin{array}{lll}\begin{array}{l}\text { Chemical } \\
0.47)\end{array} & \text { Isolate } 2 & (\mathrm{Rf} \\
\end{array}$ \\
\hline $0.1 \%$ DMSO (Control) & 1 & 0 \\
\hline 10 & $\begin{array}{c}1 \\
(30)\end{array}$ & $\begin{array}{c}3 \\
(2)\end{array}$ \\
\hline 25 & $\begin{array}{c}2 \\
(45) \\
\end{array}$ & $\begin{array}{l}45 \\
(3) \\
\end{array}$ \\
\hline
\end{tabular}




\begin{tabular}{|c|c|c|}
\hline 50 & 2 & 50 \\
& $(60)$ & $(4)$ \\
\hline 100 & 1 & 80 \\
& $(73)$ & $(8)$ \\
\hline 200 & 2 & 85 \\
& $(98)$ & $(5)$ \\
\hline
\end{tabular}

Values are mean of 3 separate determinations. Values are corrected to nearest whole number. \% of cells showing membrane blebbing is shown in brackets. Cytotoxicity was determined by Trypan Blue exclusion method. Since apoptotic cell death leads to disintegration of the cells into apoptotic bodies, in this method, cells dying by apoptosis will not be seen as intact stained cells.

Table 4. Anti-tumor activities of chloroform fraction of hexane extract from apium graveolens seeds

\begin{tabular}{|c|c|c|c|c|c|c|}
\hline \multirow{3}{*}{$\begin{array}{l}\text { Days (after } \\
\text { tumor } \\
\text { challenge) }\end{array}$} & \multicolumn{6}{|c|}{ Number of surviving animals } \\
\hline & \multirow{2}{*}{ control } & \multicolumn{3}{|c|}{$\begin{array}{l}\text { Chloroform fraction of hexane } \\
\text { extract ( } \mathrm{mg} / \mathrm{kg}, \text { b.w.) }\end{array}$} & \multicolumn{2}{|c|}{$\begin{array}{l}\text { Vincristine } \\
\text { (mg/kg, b.w.) }\end{array}$} \\
\hline & & 50 & 100 & 200 & 0.5 & 1.0 \\
\hline 1 & 8 & 8 & 8 & 8 & 8 & 8 \\
\hline 10 & 8 & 6 & 8 & 8 & 8 & 8 \\
\hline 15 & 0 & 0 & 3 & 6 & 8 & 8 \\
\hline 20 & 0 & 0 & 0 & 6 & 7 & 8 \\
\hline 40 & 0 & 0 & 0 & 6 & 0 & 4 \\
\hline
\end{tabular}

Mice were challenged with $1 \times 10^{6}$ cells (i.p.). The fraction was administered daily from the day of tumor challenge for 15 days (the time period required for the death of all the mice in the control group was 14 days)

\section{Discussion}

The present study shows for the first time the anti-cancer and apoptosis inducing property of the hexane extract of $A$. graveolens. The in vivo anti-cancer activity of chloroform fraction (AF) from hexane extract was found to be very promising. Since this fraction contained both apoptosis inducing and necrosis causing components, further studies are required to determine the efficacy of these components separately. Further the apoptosis inducing principle has been tentatively identified as a steroid positive component. This is an attractive material for further studies leading to the possible development of a useful chemotherapeutic agent.

Although it induced apoptosis, the apoptotic mechanism remains to be studied. Detailed studies in various experimental cancer models are required to establish efficacy. It is of interest to note that the cancer cells are more susceptible compared to normal cells. However, there is a need to test the sensitivity of many other types of cancer cells as well as normal cells to determine the likely, beneficial effects of observed cell specific efficacy in the treatment of cancer. Besides acute and subacute toxicity evaluation has to be carried out to determine the likely safety of the extract and or active component. At any rate, the present study has opened up a new vista for further studies. 
South American Journal of Medicine

Special Edition 2016
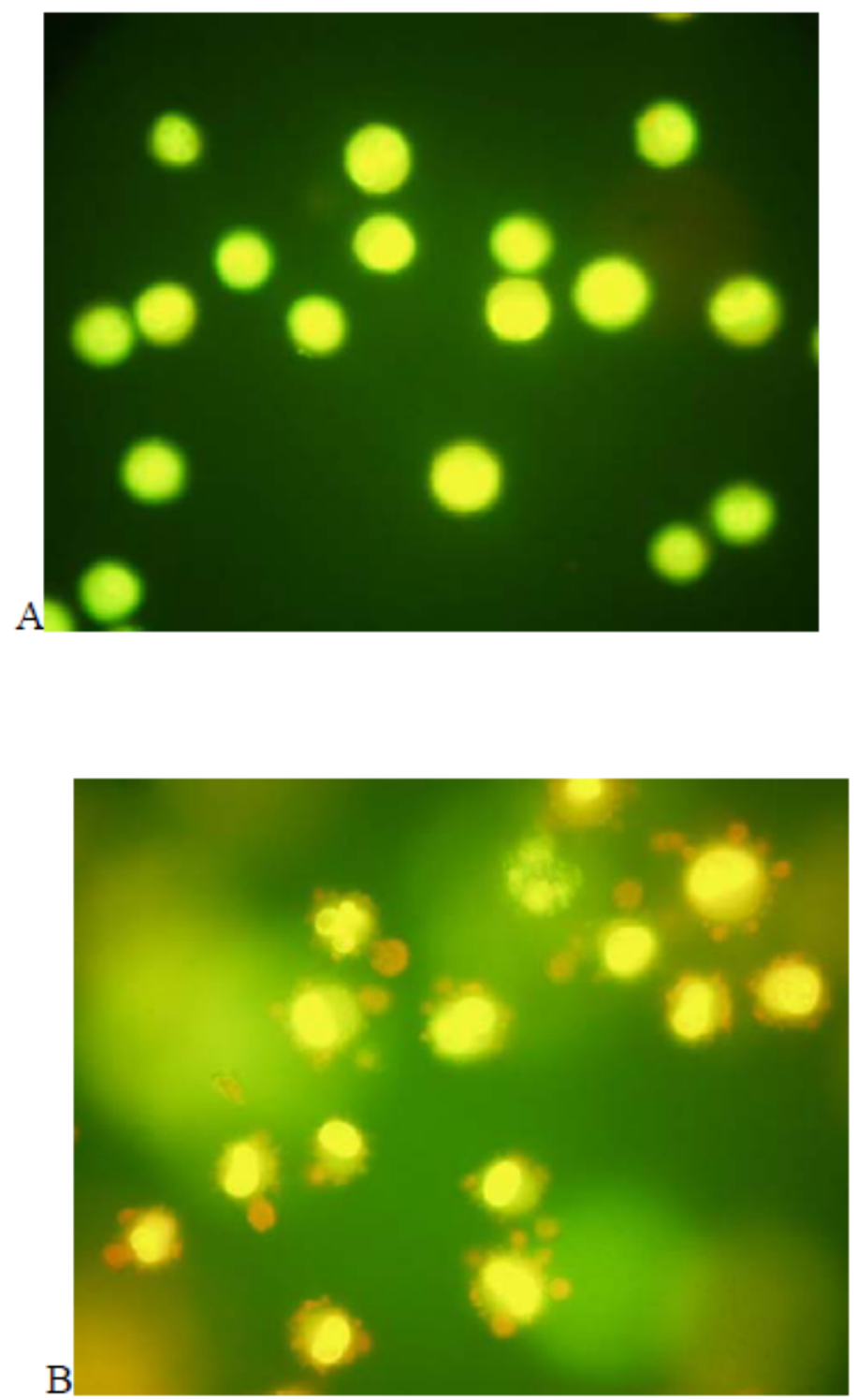

Fig. 1. Induction of apoptosis in dalton's lymphoma ascites (DLA) cells by an active steroid positive component (fraction) from $A$. graveolens seed

A. Control (stained with acridine orange and ethidium bromide)

B. The steroid positive component (fraction) treated cells showing membrane blebbing and formation of apoptotic bodies

\section{References}

[1]. Pushpangadan P, Subramoniam A. Pharmacological investigations on Indian medicinal plants: a search for anti-cancer agents. Amala Research Bulletin 1998: 18:123-129

[2]. Subramoniam A. Defining molecular targets in the discovery of phytomedicines for cancer. Amala Res Bull 2001: 2: 82-87.

[3]. Bertram JS. Cancer prevention by carotenoids. Mechanistic studies in cultured cells. Ann N Y Acad Sci 1993: 691: 177-191.

[4]. Blot WJ, Li J-Y, Taylor PR, et al. Nutrition intervention trials in Linxin, China: Supplementation with specific vitamin/mineral combinations, cancer incidence, and disease specific mortality in the general population. J Natl Cancer Inst 1995: 85: 1483- 1492.

[5]. Menon LG, Kuttan R, Kuttan G. Inhibition of lung metastasis in mice induced by B16F-10 melanoma cells by polyphenolic compounds. Cancer Lett 1995: 95: 221-225. 


\section{South American Journal of Medicine \\ Special Edition 2016}

[6]. Cardile V, Scifo C, Russo A, Falsaperla M, Morgia G, Motta M, Renis M, Imbriani E, Silvestre G. Involvement of HSP70 in resveratrol-induced apoptosis of human prostate cancer. Anticancer Res. 2003: 23: 4921-4926.

[7]. Crowell PL. Prevention and therapy of cancer by dietary monoterpenes. J Nutr 1999: 129: 775S$778 \mathrm{~S}$.

[8]. Jose JK, Joy KL, Kuttan R. Effect of Emblica officinalis, Phyllanthus amarus and Picrorrhiza kurroa on N-nitrosodiethylamine induced hepatocellular carcinogenesis. Cancer Letter 1999: 135: 1-6.

[9]. Joy KL, Kumar NV, Kuttan G, Kuttan R. Effect of Picrorrhiza kurroa extract on transplanted tumors and chemical carcinogenesis in mice. J Ethnopharmacol. 2000: 71: 261-267.

[10]. Subramoniam A, Rajasekharan S, Latha PG, Evans DA and Pushpangadan P. Immunomodulatory and anti-tumor activities of Janakia arayalpathra. Fitoterapia 1996: 57: 140-144.

[11]. Subramoniam A. Role of cis unsaturated fatty acids in cell growth regulation. Amala Res Bull 1997:17: 27-31.

[12]. Subramoniam A, Rajasekharan S, Pushpangadan P, George V, Nair SG. A process to prepare an herbal formulation for cancer from Janakia arayalpathra root and Trichopus zeylanicus leaf. Inventors (Chennai/2001). Patent No: MAS/659/01(Patent obtained).

[13]. Mehta RG, Pezzuto, JM. Discovery of cancer preventive agents from natural products: From plants to prevention. Curr Oncol Rep 2002: 4: 478-486.

[14]. Shylesh BS, Ajikumaran Nair S, Subramoniam A. Induction of cell specific apoptosis and protection from Daltons' Lymphoma challenge in mice by Emilia sonchifolia (active fraction) containing a terpene, active principle. Indian J Pharmacol 2005: 37:232-237.

[15]. Subramoniam, A, Subhisha S, Ajikumaran Nair S, Shylesh BS, Nair G.M. Bryophytes of Kerala: a potential source of anti-cancer agents. Amla Res. Bull.2003: 23: 78-83

[16]. Hanahan D, Weinberg RA. Resistance to apoptosis and cancer. Cell, 2000: 100: 57- 70.

[17]. Martin Z, Anne-Odile H, Wiebke B, Gerard E. Apoptosis regulators and their role in tumorigenesis. Biochem Biophys Acta, 2001: 1551:F1-F37.

[18]. Green DR, Kroemer G. The pathophysiology of mitochondrial cell death. Science, 2004: 305 : 626-629.

[19]. Subramoniam A., Ajikumaran Nair S. Application of apoptosis in the search for plant-derived chemopreventive/therapeutic agents. Amala Research Bulletin, 2004: 24: 1-11.

[20]. Shaik Imam, Hussain SJ. Some important herbs used in the treatment of cancer: part-1. In: Role of biotechnology in medicinal and aromatic plants. I A Khan \& A Khanum (eds) 2004: Volume 11, 150. Ukaaz Publications, Hyderabad.

[21]. Choochote W, Tuetun B, Kanjanapothi D, Rattanachanpichai E, Chaithong U, Chaiwong P, Jitpakdi A, Tippawangkosol P, Riyong D, Pitasawat B. Potential of crude seed extract of celery, Apium graveolens L., against the mosquito Aedes aegypti (L.) (Diptera:Culicidae). J Vector Ecol. 2004: 29: 340-346.

[22]. Seetharami Reddi TVV, Prasanthi S and Ramarao Naidu BVA. Medicinal and aromatic plants of India. In: Role of biotechnology in medicinal and aromatic plants. I A Khan \& A Khanum (eds) 2005:

Volume12,1-146. Ukaaz Publications, Hyderabad.

[23]. Mary KT, Kuttan G, Kuttan R. Partial purification of tumour reducing principles from Helianthes elastica. Cancer Lett. 1994: 81: 53-56.

[24]. Wagner H, Bladt S, Zgainski EM. Plant drug analysis. Berlin, Heidelberg, New York, Tokyo; Springer-Verlag, 1984. 